\title{
Религиозно-антропологические аспекты духовно-нравственного воспитания в российской педагогике XX века
}

\author{
Сахаров Василий А. \\ Кафедра Философии, Социологии и Психологии \\ Вятский Государственный Университет \\ vas701@rambler.ru \\ Сахарова Людмила Г. \\ Кафедра Социальных Наук \\ Кировской Государственной Медицинской Академии \\ vas701@rambler.ru
}

\begin{abstract}
Sakharov V.A., Sakharova L.G., The Religious and Anthropological Aspects of Spiritual and Moral Upbringing in the Russian Pedagogy of the 20th Century, Elpis, 16 2014: 211-214.
\end{abstract}

Сахаров В.А., Сахарова Л.Г., Religijno-antropologiczne aspekty duchowego i moralnego wychowania w rosyjskiej pedagogice XX wieku, Elpis, 16 2014: 211-214.

Abstract: This article analyzes the pedagogical legacy of the beginning of $20^{\text {th }}$ century dedicated to the problem of spiritual and moral upbringing of youth according to the anthropology of Orthodox Christianity.

Streszczenie:_W tym artykule opisano problem duchowego i moralnego wychowania osobowości z punktu widzenia prawosławnej antropologii i jej odzwierciedlenie w krajowym pedagogicznym dziedzictwa XX wieku

Аннотация: В статье рассматривается проблема духовно-нравственного воспитания личности с точки зрения православной антропологии и ее отражение в отечественном педагогическом наследии XX в.

Keywords: spiritual and moral upbringing, youth, history of education, moral senses, emotional sphere of a personality

Słowa kluczowe: duchowe i moralne, młodzież, historia pedagogiki, uczucia moralne, emocjonalne osobowości

Ключевые слова: духовно-нравственное воспитание, молодежь, история педагогики, нравственные чувства, эмоциональная сфера личности

Многогранный исторический опыт показывает, что среди огромного количества решаемых человечеством задач, особое место всегда занимали и занимают проблемы развития духовности и нравственности людей, от которых зависит жизнь и деятельность общества и государства.

По словам академика Д.С. Лихачева «..нравственная основа - это главное, что определяет жизнеспособность общества: экономическую, государственную, творческую. Без нравственной основы не действуют законы экономики и государства, не выполняются указы: Без нравственности невозможно развитие любой науки..» ${ }^{1}$.

Для нашей страны слова остаются актуальными и сегодня. Перестройка и последовавшие за ней 1990-е гг. вызвали деструктивные процессы в общественной нравственности, гражданском самосознании, а затем и в социально-экономической сфере. Одним из возможных путей исправления сложившейся ситуации на современном этапе является духовно-нравственное

Лихачев, Д. С. «Русская культура».- М.: «Искусство», 2000, с. 155. воспитание личности: расширение духовного потенциала, обогащение поведенческой культуры на основе нравственных ценностей.

В истории российского образования в XX в. проблема духовно-нравственного воспитания получила свое отражение, как в религиозно-философских исследованиях (Н. А. Бердяев, С. Н. Булгаков, И. А. Ильин, Н. И. Лосский, Г. П. Федотов др.), так и в работах психолого-педагогической направленности (П. П. Блонский, В. П.Вахтеров, К. Н. Вентцель, В. В. Зеньковский, П. Ф. Каптерев, С. С. Куломзина, П. Ф. Лесгафт, Б. А. Ничипоров, А. Н. Острогорский, М. М. Рубинштейн, В. А. Сухомлинский, И. П. Иванов и др.). В 1990-е 2000-е гг. выполнено значительное число научно-теоретических и опытно-практических разработок по данной проблеме. (К. А. Абульханова-Славская, Ш. А. Амонашвили, В. А. Беляева, Н. А.Белканов, Е. П. Белозерцев, Е. В. Бондаревская, Т. Н. Власова, Б. В. Емельянов, В. А. Караковский, И. А. Колесникова, С. В. Кульневич, А. И. Осипов, Т. И. Петракова, В. Л. Слободчиков Э. А.Чурсина и др.).

Можно утверждать, что объяснение феномена ду- 
ховно-нравственного воспитания принадлежит, как минимум, двум основным подходам -религиозному и, условно называемому, светскому.

В светской педагогике данное направление воспитания связано с развитием. Светская трактовка этого термина (от ярко выраженной классовой, марксистской до более мягкой культурологической, гуманистической) «исходит из материалистического определения человека как «продукта среды» и поэтому преследует задачу, прежде всего, ее улучшения, облагораживания, создания соответствующих условий через правильную организацию детской жизни и деятельности, включая также и «подгонку» индивида к среде. По мнению одной из современных исследовательниц проблем духовно-нравственного воспитания В. А. Беляевой, проблема духовно-нравственного воспитания как проблема духовной и душевной жизни человека в светской педагогической культуре вообще не ставилась и не рассматривалась. Целевые установки воспитательного процесса были представлены общей глобальной целью - воспитанием всесторонне развитой гармонической личности, - и ее конкретизацией по выделенным направлениям воспитания, которых насчитывалась более двадцати. Духовное воспитание в педагогике при этом отмечалось лишь фрагментарно, внутри отдельных направлений, как задача воспитания правильного восприятия нематериальных ценностей музыки, живописи, литературы ${ }^{2}$

В религиозной (православной) педагогике понимание процесса духовно-нравственного воспитания опирается на христианскую антропологию (традиционное учение Церкви о его природе и сущности человека, которое неразрывно связанная с христианской антропогонией (учением о происхождении человека) и христианской сотериологией (учением о конечной цели его бытия)).

Согласно христианской антропологии, человек, создан по образу и подобию Творца и является венцом творения и одновременно ипостасью космоса, причастного его природе. Его природа дуалистична, поскольку, одновременно принадлежит двум мирам: физическому - это его тело, и невидимому, духовному, трансцендентному - это его душа. «Та неизменная устойчивость личности, которую мы подразумеваем под словом «я», создающая идентичность нашей индивидуальности, - пишет митрополит Питирим (Нечаев), - определяется с точки зрения христианской антропологии именно душой, нематериальным субстратом, в котором заложена вся информация о нашем «я». ${ }^{3}$

Православная антропология задает образ совершенного человека, к которому стремится всякий

Беляева В. А. Теория и практика духовно-нравственного становления и развития личности в светской и православной педагогической культуре - автреф. дисс. на соиск. уч.степ. д.П.н. (13.00.01) - М.,1999

3 Митрополит Питирим. Тело, душа, совесть: (Учение о человеке в христианской традиции и современное общество). - В кн.: Малая церковь. М., 1992. С.208 православный христианин. Отношения человека с Образцом строятся не как его достижение, но как преображение (теозис) индивида в процессе соединения с Ним, при сохранении уникальности личности стремящегося. Тем самым христоцентричная антропология устремляет человека в «горнее», в трансцендентное (которое одновременно является и имманентным человеку в силу его - человека - богообразности). ${ }^{4}$

Образ Божий человеку дан, подобие - задано, поэтому конечная цель его жизни - достичь Богоподобия (обожения, святости) при благодатной помощи свыше. Образ Божий начертан в высших свойствах человеческой души - бессмертии, свободе воли, разуме, способности к чистой, бескорыстной любви (И.А.Ильин, Н.И.Лосский, С.Н.Трубецкой, Г.П.Федотов, С.Л.Франк и др. $)^{5}$

Духовно-нравственное воспитание при этом понимается как целенаправленная деятельность, нацеленная на приобщение человека к Вышнему и Горнему миру, на постепенное восстановление целостной структуры личности, самоопределение человека и совершенствование его в добродетели. ${ }^{6}$

В православной педагогической культуре цель духовно-нравственного воспитания выражена в установке образовательного и воспитательного процессов на «воссоздание в человеке образа Божия», формирование у него потребности жить по заповедям высокого духовного и нравственного бытия, приобщение его к ценностям, находящимся в высшей иерархии ценностей жизнедеятельности человека. «Наше вмешательство в жизнь ребенка имеет смысл лишь в том, чтобы помочь раскрытию образа Божия в ребенке и устранить все то, что замедляет это раскрытие... Раскрытие образа Божия, становление внутреннего человека - это есть то, помочь в чем и должно воспитание». ${ }^{7}$

В святоотеческой психологии в строении души выделяют три части: мыслительную (воображение, память, рассудок,); желательную (потребности, желания, и т.д.) и чувственную («сердце»). По учению Церкви - Сердце, это часть души, то место, в котором при определенных условиях происходит Богообщение, где действует благодать Божия. ${ }^{8}$ Именно сердце обладает способностью восприятия духовных воздействий. «Сердцем человек молится, т. е. говорит с Богом. Прежде всего на сердце воздействует Творец, желая испра-

\footnotetext{
4 Остапенко М. А. Образ совершенного человека в православной антропологии - Автореф. дисс. на соиск. уч.степ. к.фил.н. ... Екатеринбург,2002. -С.9

5 Петракова Т.И. Духовно-нравственное воспитание в условиях общеобразовательной школы: категории, содержание, критерии http://www.verav.ru/common/mpublic.php?num=18

6 Программа духовно-нравственного воспитания дошкольников //«Дошкольное воспитание»- 2004-№ 5

Беляева В.А. Теория и практика духовно-нравственного становления и развития личности учителя в светской и православной педагогической культуре - Автореф. дисс. на соиск. уч.степ. д.п.н. (13.00.01) - М.,1999. - С.7

8 Митрополит Иерофей (Влахос) Православная духовность. - Свято-Троицкая Сергиева Лавра, 1999. - С. 32.
} 
вить человека» ${ }^{9}$. Очевидно, что с воспитанием сердца связано воспитание мотивов к той или иной деятельности.

Исходя из этого духовно-нравственное воспитание в православной педагогической традиции можно рассматривать как «воспитание сердца» (В.В.Зеньковский, И.А.Ильин, Н.И.Лосский, Т.И. Петракова и др.).

«...Объектом духовно-нравственного воспитания, - пишет Т.И. Петракова в работе «Духовные основы нравственного воспитания» - является сердце человека. ... для духовного существа человека, его души, сердце является не просто средоточием чувств, переживаний, настроений, а таким центром, проходя через который эти переживания, настроения, чувства изменяются, приобретают определенную «окрашенность», светлеют или, напротив, омрачаются, темнеют - в зависимости от «силы сердца в любви», этого высшего, самого глубокого и напряженного сокровенного человеческого чувства..». Цель духовно-нравственного воспитания состоит в превращении «сердца эгоистического в сердце всескорбящее» ${ }^{10}$ т.е. в воздействии на эмоционально-мотивационную сферу личности, ориентированном на развитие ее нравственных чувств.

Именно нравственные чувства - любовь, совесть И др. - составляют содержание эмоциональной «жизни сердца». По словам Свт. Феофана (Затворника) «жизнь сердца есть любовь».

Любовь к Богу и сострадание к человеку являются основой отношений человека ко всему сущему, ко всем другим людям, а также к вещам, предметам и явлениям действительности. «Любовь к Богу, - пишет прот. И. Базаров, - собственно не есть заповедь, а только указание на естественную потребность неиспорченной природы человека. Дух Божественный, присущий естеству человеческому, естественно стремится к своему первоисточнику и в этом стремлении находит свое блаженство» ${ }^{11}$

Об этом же пишет русский философ И. А. Ильин, утверждая, что необходимо как можно раньше «зажечь и раскалить» в ребенке «духовный уголь»: чуткость ко всему Божественному, волю к совершенству, радость любви и вкус к доброте». ${ }^{12}$

Развитие этого нравственного чувства тесно связано с воспитанием совести. Совесть - одно из выражений нравственного самосознания личности, голос нашего внутреннего «я», помогающий человеку отличать, что является добром и что злом, чувствовать и осознавать ответственность за себя.

Наряду с любовью, в христианстве совесть считается самым значительным проявлением духовности в

\footnotetext{
Петракова Т.И. Духовные основы нравственного воспитания,Москва:ИМПЭТО,1997 - 83 с.

10 Петракова Т.И. Духовные основы нравственного воспитания,Москва:ИМПЭТО,1997 - 83 с.

11 Базаров Иоанн, прот. Нравственность и жизнь. Странник. СПб, 1878. С. $187-195$.

12 Ильин, И.А. Путь духовного обновления. //Собр. соч.: В 10 т. [Текст]/ И.А. Ильин. Т. 1.- М., 1993. - с. 156-157
}

человеке. Она является действующей силой души, ее центром, проявлением в человеке «голоса Божьего», того естественного нравственного закона, который Бог начертал в сердцах людей. «...Вопреки нашим помыслам, стремлениям и интересам, - пишет профессор А. Гусев, - мы чувствуем в себе присутствие как бы особой силы, царящей над нашими помыслами, влечениями и хотениями, властно повелевающей нам и угрожающей мучительною карою за пренебрежение к ее требованиям, но в то же время неотделимой от нас» ${ }^{13}$.

На основе анализа православного педагогического наследия исследователи отмечают, что среди рекомендаций по «воспитанию сердца» большую часть составляют те, которые ориентированы на актуализацию эмоциональной сферы личности и развитие ее нравственных чувств. Это:

«-развитие эмоциональной сферы ребенка, его интуиции как первоначального умения «чувством познавать жизнь»;

- воспитание чувства любви к Богу, ко всему высокому и святому как основе нравственного воспитания. $<\ldots>$

- обучение детей адекватному выражению своих чувств, ...

- поддержание «огня сердца», воспитание любви во всех ее проявлениях (через любовь к животным, природе и т. п.).»

- использование житийной литературы, обращение к образам святых, имена которых носят дети с тем, чтобы у них сложился достаточно полный и живой нравственный идеал.

- Словесные образы, на которых воспитывается ребенок, необходимо по возможности подкреплять другими образами и образцами святости - музыкальными, живописными, архитектурными, драматическими и т. д., целостной системой художественных образов. Усиление за счет этого эмоционального поля приводит к повышению эффективности воспитательного воздействия, позволяет практически осуществить «правильный подбор впечатлений и представлений» (К. Д. Ушинский), необходимых для духовно-нравственного воспитания и образования. ${ }^{14}$

Говоря о принципах духовно-нравственного воспитания, (таких как одухотворенность образовательного процесса, соборность, иерархичность, ориентация на нравственный Идеал, воспитание примером и духовная укорененность), С.И.Маслов также выделяет среди них принцип «приоритета эмоционального в постижении мира» ${ }^{15}$

Таким образом, в религиозной (православной) педагогике цель духовно-нравственного воспитания выражена в установке образовательного и воспитатель-

\footnotetext{
13 Гусев А. Религиозность как основа нравственности: Против автономистов. Изд. 2-е. Казань, 1894

14 Петракова Т.И. Духовные основы нравственного воспитания,Москва:ИМПЭТО,1997 - 83 с

15 Маслов С.И. Дидактические основания духовно-нравственного воспитания//Педагогика - 2008 - № 9 -С.46-51
} 
ного процессов на «воссоздание в человеке образа Божия», формирование у него потребности жить по заповедям высокого духовного и нравственного бытия, приобщение его к ценностям, находящимся в высшей иерархии ценностей жизнедеятельности человека. Воспитание должно быть направлено на восстановление человеческой природы, на правильное иерархическое устроение трех сторон человека - духа, души и тела, то есть на создание условий, способствующих рождению духовной жизни и ее развитию в человеке.

Особое значение в духовно-нравственном воспитании имеет развитие нравственных чувств ( любовь, совесть, сострадание и др.) через воздействие на эмоциональную сферу воспитанника.

\section{Литература}

Базаров, Иоанн, прот. Нравственность и жизнь. Странник. СПб, 1878.

Беляева, В.А. Теория и практика духовно-нравственного становления и развития личности учителя в светской и православной педагогической культуре - Автореф. дисс. на соиск. уч.степ. д.п.н. (13.00.01) - М.,1999.

Гусев. А. Религиозность как основа нравственности: Против автономистов. Изд. 2-е. Казань, 1894.

Ильин, И.А. Путь духовного обновления. //Собр. соч.: В 10 т. [Текст]/ И.А. Ильин. Т. 1.- М., 1993. - с. 156-157

Лихачев , Д.С. «Русская культура».- М.: «Искусство», 2000

Маслов, С.И. дидактические основания духовно-нравственного воспитания//Педагогика - 2008 - № 9 -С.46-51

Митрополит Иерофей (Влахос) Православная духовность. Свято-Троицкая Сергиева Лавра, 1999.
Митрополит Питирим. Тело, душа, совесть: (Учение о человеке в христианской традиции и современное общество). - В кн.: Малая церковь. М., 1992.

Остапенко М.А. Образ совершенного человека в православной антропологии - Автореф. дисс. на соиск. уч.степ. к.фил.н. ... -Екатеринбург,2002.

Петракова Т.И. Духовные основы нравственного воспитания,- Москва:ИМПЭТО,1997 - 83 с.

Петракова Т.И. Духовно-нравственное воспитание в условиях общеобразовательной школы: категории, содержание, критерии http://www.verav.ru/common/mpublic. php?num $=18$

Программа духовно-нравственного воспитания дошкольников//«Дошкольное воспитание»- 2004-№ 5

Rozmiar artykułu: 0,5 arkusza wydawniczego 